\title{
Using WhatsApp for co-creation of learning resources: A case of a South African university
}

\begin{tabular}{|c|c|}
\hline \multicolumn{2}{|c|}{$\begin{array}{l}\text { Authors: } \\
\text { Patient Rambe }{ }^{1} \text { (D) } \\
\text { Crispen Chipunza }{ }^{1} \\
\text { Dick Ng'ambi }^{2} \text { (D) }\end{array}$} \\
\hline \multicolumn{2}{|c|}{$\begin{array}{l}\text { Affiliations: } \\
{ }^{1} \text { Department of Business } \\
\text { Support Studies, Faculty of } \\
\text { Management Sciences, } \\
\text { Central University of } \\
\text { Technology, Bloemfontein, } \\
\text { South Africa }\end{array}$} \\
\hline \multicolumn{2}{|c|}{$\begin{array}{l}{ }^{2} \text { School of Teacher Education, } \\
\text { Faculty of Education, } \\
\text { University of Cape Town, } \\
\text { Cape Town, South Africa }\end{array}$} \\
\hline \multicolumn{2}{|c|}{$\begin{array}{l}\text { Research Project Registration: } \\
\text { Project Number: } 10 / 2020\end{array}$} \\
\hline \multicolumn{2}{|c|}{$\begin{array}{l}\text { Corresponding author: } \\
\text { Crispen Chipunza, } \\
\text { cchipunza@cut.ac.za }\end{array}$} \\
\hline \multicolumn{2}{|c|}{$\begin{array}{l}\text { Dates: } \\
\text { Received: } 21 \text { Nov. } 2019 \\
\text { Accepted: } 30 \text { June } 2020 \\
\text { Published: } 22 \text { Sept. } 2020\end{array}$} \\
\hline \multicolumn{2}{|c|}{$\begin{array}{l}\text { How to cite this article: } \\
\text { Rambe, P., Chipunza, C. \& } \\
\text { Ng'ambi, D., 2020, 'Using } \\
\text { WhatsApp for co-creation of } \\
\text { learning resources: A case of a } \\
\text { South African university', The } \\
\text { Journal for Transdisciplinary } \\
\text { Research in Southern Africa } \\
\text { 16(1), a791. https://doi. } \\
\text { org/10.4102/td.v16i1.791 }\end{array}$} \\
\hline \multicolumn{2}{|c|}{$\begin{array}{l}\text { Copyright: } \\
\text { (C) 2020. The Authors } \\
\text { Licensee: AOSIS. This } \\
\text { is licensed under the } \\
\text { Creative Commons } \\
\text { Attribution License. }\end{array}$} \\
\hline \multicolumn{2}{|l|}{ Read online: } \\
\hline 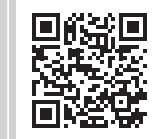 & $\begin{array}{l}\text { Scan this QR } \\
\text { code with your } \\
\text { smart phone or } \\
\text { mobile device } \\
\text { to read online. }\end{array}$ \\
\hline
\end{tabular}

Although culturally diverse students have potential to create enriched learning resources, it is difficult to harness students' agency and to aggregate individual contributions into a meaningful learning resource. This is one of the challenges facing higher education institutions in South Africa where institutions are increasingly cosmopolitan and culturally diverse, but production of knowledge has largely remained skewed in favour of those students with unlimited access to learning resources, the Internet and peer networks, anywhere, anytime. Although the appropriation of emerging technologies such as mobile phones has enabled a digital sharing culture, this social practice has not been harnessed for co-creation of learning resources. This article reports on a study that sought to uncover the extent to which the use of WhatsApp-enabled phones facilitated the co-creation of learning resources in a human resource management programme at a university of technology in South Africa. The article employed Amartya Sen's capabilities framework to analyse WhatsApp interactions of 72 participants from underprivileged backgrounds. The article concludes that leveraging students' capabilities, including rich culturally diverse knowledge, is not a mere outcome of access to a tool such as WhatsApp, but requires pedagogical designs that exploit the affordances of the tool.

Keywords: WhatsApp; MIM; collectively generated resources; dialogic interactions; learning resources.

\section{Introduction}

The phenomenal surge in ownership of mobile phones among South Africans and at South African higher educational institutions (SAHEIs) has accentuated the clarion call for the integration of such devices into tertiary teaching and learning. O'Dea (2020) reported that in March 2020, about 23.3 million South Africans owned smartphones, which constitutes approximately a third of the country's population. By 2023, the figure on mobile ownership would be 26.3 million (O'Dea 2020). Similarly, a study conducted by North, Johnston and Ophoff (2014) revealed that $99 \%$ of students at the University of Cape Town owned mobile devices. The claim about universal mobile ownership among students at SAHEIs is corroborated by Shava, Chinyamurindi and Somdyala (2016) who reported that most Technical and Vocational Education and Training (TVET) students owned smartphones with instant messaging, data and information exchange and speedy Internet access capabilities.

Despite an increasing ownership of mobile phones among students at SAHEIs, there is a paucity of empirical evidence to suggest that the adoption of mobile phones is changing university teaching and learning practices. Although the popularity of smartphones presents an opportunity for HEIs to integrate student-owned mobile phones into institutional information and communication technologies (ICT) infrastructure, the academic uptake of mobile phones for instructional purposes at SAHEIs has been disappointing. Some scholars have attributed this mobile inertia to the following:

- educators' lack of pedagogical knowledge to integrate mobiles' usage in didactic lectures (Rambe \& Bere 2013);

- insufficient theoretical and pedagogical guidelines on mobile phone-mediated pedagogies (Bozalek et al. 2014);

- fears of replicating socio-technical marginalisation, itself a reflection of demographic legacies of inequality in South Africa (Madge et al. 2019).

Although these challenges provide insight into the reasons for the low uptake of mobile phones at SAHEIs, they do not explain the gulf between ownership (hence access to applications for knowledge sharing) and willingness to engage in cross-cultural knowledge-sharing 
practices. It was this phenomenon that motivated this study to explore the impact of student ownership of mobile phones on their academic agency (i.e. choice to contribute to shared learning resources in situations where (1) an educator may or may not have required it as a pedagogical strategy and (2) access to peers for face-to-face interaction is constrained by either time or distance). We identify with Moore's (2016) definition of agency as the feeling of control over choices and actions and their consequences. As student agency encapsulates their access to mobile resources, grasp of their functionalities and possession of competencies to use them, exploring agency is critical to student-effective use of mobile phones for learning.

Mindful of the fact that agency manifests in students' deployment of their learning skills, competencies and capabilities to make meaningful choices about how, when and with what resources they learn, it (i.e. agency) therefore reshapes itself in relational terms of articulation; of the vested interests of learners; the new roles and positions that some occupy and others do not; and in terms of the novel situations in which all students find themselves (Archer 2010). Gorski (2005) argues that high levels of agency provide a useful avenue for breaching digital inequities and mobilising appropriate skills to accomplish intended goals. To the extent that students are generally competent users of mobile phones, we wondered about the gulf between social uses of mobile phones (social agency) and mobile uses for meaningful engagement to achieve pedagogical goals (academic agency).

As agency resonates with assessment of one's mental state and corresponding actions (Sen 1985a) in response to situated conditioning circumstances, this study bridges the gap between social and academic agency by employing Sen's capabilities approach to explore the potential of a mobile phone application, WhatsApp, to enhance the academic agency of students at a South African university. With its focus on agents' capabilities, functionality of the tool and perceived freedoms (e.g. affordances and constraints), Sen's capabilities approach provides a vantage point for exploring the nexus between mobile phone access and student agency in a higher education context.

\section{Research questions}

In resource-constrained environments such as the South African Universities of Technology (UoTs), the augmentation of institutionally provided ICT infrastructure with devices owned by students is an obvious choice. However, students have regulated freedom when using ICTs provided by institutions such as learning management systems (LMSs) and therefore are likely to view WhatsApp as providing opportunities for unregulated freedom. As such, the relationship between students' possession of mobile phones and their academic agency needs to be explored to ensure productive use of collaboratively generated content. We distinguish the functionings of 'being' and 'doing' (Sen 1985a): 'being' as allowing a practice of sharing (i.e. doing) to become a social practice as opposed to a one-off social act. Our thesis is that it is the aggregation of social acts (i.e. the 'doings' as in posting of text, photos and videos in mobile instant messaging [MIM]) that results into a collaboratively shared artefact. As freedom, itself the actual ability of a person to achieve valuable functioning, should have instrumental relevance (i.e. its value as a means to other ends) (Sen 1985a), we assume that student participation in these social acts enabled by technology can shape and increase their academic capabilities (e.g. as knowledge generators, effective collaborators). Mindful of the complexity and serendipitous nature of mobile media engagement by previously disadvantaged students (PDSs), optimal access and use of mobile phones cannot always be anticipated. Considering the foregoing discussion, the following research questions are posed:

- How does students' access to mobile phones shape their capabilities as agents engaging in 'being' and 'doing'?

- How does their ownership of WhatsApp-enabled phones enhance their agency to co-create learning resources?

\section{Theoretical framework Social learning theory}

Ideally, the aforesaid questions can be researched and analysed from a multiple lens such as social learning theory, social network theory and capabilities framework. Social learning is a complex amalgam of computer-supported collaborative learning (Scardamalia \& Bereiter 2006) and social learning (Vygotsky 1978). Vygotsky (1978) argued that internal consciousness (i.e. psychological development) is a consequence of individuals' social interaction with social beings, objects and materials. Therefore, consciousness is socially mediated through learners' interaction with peers, educators, facilitators and artefacts before it is internalised through internal psychological processing. Social learning theory further postulates that humans use observation and imitation to learn from their interactions with others in a social context (Bandura 1977; Nabavi 2012). Upon observing the behaviours of others, people assimilate and imitate that behaviour, especially if their observational experiences are positive ones or include rewards related to the observed behaviour (Nabavi 2012).

From a social learning perspective, it can be argued that social interactions are the seedbed through which individuals learn in communities and groups (Huang, Spector \& Yang 2019). As students interact with their peers, educators and facilitators, and learning materials, objects and activities are collaboratively cocreated, shared and disseminated through WhatsApp groups, opportunities to learn socially from each other are created. Social media support social learning by facilitating collaboration (i.e. shared creation) (Schrage 1990) and knowledge creation and aid students' deep understanding (Resta \& Laferrière 2007) and flexibility of time and space (Huang et al. 2019). The argument is that through continual communication and interaction, students gain confidence in self-articulation and reflection, allowing for deep learning to happen. More so, question-based interactions can facilitate Socratic dialogues that enhance students' intellectual development. 
However, the main criticism levelled against social learning is its failure to sufficiently acknowledge differential levels of understanding among group members, which can reproduce social hierarchies in terms of knowledge construction. Furthermore, social learning theory simplifies learning by assuming that the presence of artefact mediation supports expansive learning, which is not always the case as this depends on social context of interaction, academic maturity of learners to remain task focussed and the duration of the interaction. Therefore, although this theory is useful in explaining social interaction and collaboration as the sources of social learning, the theory fails to acknowledge the fundamental role of capabilities and agency as shaped by academic maturity of learners in shaping social learning dynamics.

\section{Social network theory}

The collaborative generation of learning resources can also be studied from a social learning theoretical lens, which emphasises examining learning from the perspective of social networks. A social network is a social structure made up of individuals (or organisations) called nodes, which are connected by specific types of interdependency, such as interaction, friendship and kinship (Huang et al. 2019). A WhatsApp group serves as a social network to the extent that it comprises individuals connected to other persons (e.g. peers, educators and facilitators) who share resources, artefacts, mutual trust and social interaction, to facilitate social learning. Therefore, social network theory focusses on the role of social relationships in transmitting information, channelling personal or media influence and enabling attitudinal or behavioural change (Liu et al. 2017).

At the core face of social network theory, there are sociogram, centrality and density of the social network. The sociogram comprises the nodes, line and arrows. The node represents the actor, the line represents the relationship between actors and the arrow direction represents the information flow (Haythornthwaite \& De Laat 2010). Therefore, the WhatsApp group member who shares substantial learning resources, questions, objects and activities with his or her peers would be represented by a bigger node compared with his or her peers. The density of the network describes the degree of connectivity of an individual. It comprises the number of ties an actor has, divided by the total possible ties an actor could have (Haythornthwaite \& De Laat 2010). Therefore, the width of the line connecting nodes within a WhatsApp group sociogram demonstrates density of the network between any two given interactants (e.g. studentpeer, educator-student). Centrality describes the number of ties an actor has. One deciphers that the student or educator who has the highest connections within a WhatsApp group has the higher centrality.

However, although the social network theory is critical in demonstrating the source of knowledge by highlighting individuals who sustain interactions and the sharing of resources the most, the theory does not provide explanations for the high or low level of interactions in the network. Further, while in-degree and out-degree interactions are useful in showing which interactants provide and receive most comments, information and artefacts from the group, respectively, the theory is not useful for showing the qualitative nature of relationships as relationships are only illustrated quantitatively in terms of numbers of posts or comments.

\section{Amartya Sen's capabilities approach}

In view of the limitations of the social learning and social network theories in illuminating understanding of capabilities and the quality of knowledge co-constructed, the capabilities approach is advanced as a better theoretical lens. One of the fundamental principles of Amartya Sen's capability approach is the notion of 'achieved states of "being" and activities of an individual' (Kuklys 2005:5). Thus, capabilities are described in terms of what people are able to be and to do (Sen 1985b). This theory provides a way of understanding mobile phones as a way of being, and that users have capacity to act and to be depending on the affordances of the mobile application. Sen (1992) argues that the various combinations of functioning ('beings' and 'doings') are indicative of what a person can achieve. Capability is thus a 'person's freedom to lead one type of life or another [...] to choose from possible livings' (Sen 1992:40). It follows that the capability approach may provide a useful way of describing academic agency of heterogeneous students at a higher education institution, how they act and what they do with MIM. This argument is strengthened by the view that in Sen's capability theory, functionings are outcome-based as opposed to being resource-based (Kuklys 2005). The significance of viewing the constructs of 'being and doing' in terms of outcomes lies in understanding choices that students make when using MIM for collaborative knowledge sharing. Sen (1985b) also envisages capabilities as a set of real opportunities that an individual could use in one way or another. It captures a person's or group's freedom to promote or achieve valuable functionings (Alkire 2005), and it is within the context of freedom that choices are made. The affordances of multiple applications of mobile phones render users the freedom to achieve what they consider to be valuable tasks and activities.

\section{Valuable functionings}

At the core of Sen's (1987a) capabilities approach, there are two quintessential constructs of valuable functionings and freedom. Functionings denote the 'various things a person may value "doing" or being' (Sen 1999:75) that are deeply rooted in ideal welfare and productive physical and mental states. Broadened access to knowledge networks, trustworthy affinities and sound judgement are among the functionings an academically oriented learner aspires to acquire via networked communities. When conceived in its entirety, the capabilities approach encompasses all qualitative changes in human ways of life: from knowledge, 
relationships, employment opportunities and inner peace, to self-confidence and the valued activities made possible by the literacy classes (Alkire 2005). The bottom line is that education should give students access to the necessary positive resources and enable them to make choices that matter to them.

\section{Freedom}

Freedom emphasises 'the real opportunity that we have to accomplish what we value' (Sen 1992:31). It should be conceived as the actual ability of a person to employ valuable functionings (Sen 1987a). The realisation of freedom necessitates making informed choices, prudent ranking of functionings and perfect information about alternatives open to individuals. Sen (2000) argues that the exclusion of the poor from participation in and access to opportunities and activities is a constraint that needs to be recognised and addressed. In the same vein, constraints such as limited access to libraries, erratic power supply and unreliable networks can frustrate students' attempts at effective academic engagement and trigger academic exclusion in purportedly inclusive learning environments.

Sen (1987a) classifies freedom into two - 'positive' terms, where emphasis is placed on individual choices about possible actions and achievements, rather than on the absence of particular restraints that prevents his or her from making choices about possible course of action. On the contrary, 'negative' freedom describes the absence of restraints that one person may exercise over another, or the state may exercise over subjects. The pursuit of negative or positive freedom may yield qualitatively different results and our research considers both outcomes.

We understand that although they result in qualitatively different outcomes, positive and negative freedoms are not mutually exclusive because the search for virtuous life is incomplete without recourse to grasping the fundamental impediments that block its realisation. For instance, the discourse on South African students' efforts at becoming accomplished learners who engage productively with authentic knowledge is insufficient without an interrogation of PDS-constrained access to technological networks, computers and other educational resources. Previously disadvantaged students are university students emerging from under-resourced, underperforming schools and deprived socio-cultural backgrounds.

Sen's (1987a) pursuit of freedom is deeply implicated in pursuit of power in decision-making because freedom undergirds agentive action and authority to make informed choices. Consequently, the conditions of deprivation and exclusion that constrain students' accessibility to peer-based social networks for organised academic activity (e.g. discussions, critical questioning and academic support structures) are instantiations of restrained academic power.

\section{Literature review Socio-economic and cultural access}

As the study is preoccupied with students' access to mobile phones, which potentially enables collaborative generation of learning resources, the term 'access' needs some clarification to ensure its in-depth understanding in resourceconstrained environments. Bozalek, Garraway and McKenna (2011) attribute the psychological, social, cultural and financial obstacles that the first-year students encounter at universities to their socio-economic and cultural access. They observe that most students find a university to be a foreign social and cultural environment and are therefore sandwiched between excitement of being at a university and managing academic pressures. As such, one strategy of addressing these challenges is to leverage the technology and capabilities students bring with them, to ensure equity of access to educational resources and overcome historically induced imbalances in students' knowledge production. A related challenge has been the incapacity of different offering of universities to provide sufficient access to learning resources and accommodate students' diverse circumstances such as those working full time and studying part time, as well as those studying in situ at 'home' (Waters \& Leung 2013), through branch campuses (Lane 2011; Madge et al. 2019).

Tondeur et al. (2010) reconceptualise access as varying patterns of attitudes, competencies and uses of ICTs that constitute differences in cultural capital. Cultural capital that determines cultural access to ICTs is a function of cultural backgrounds and historical contexts of ICT users, which invariably shape the ICT competencies and skills they deploy to effectively use digital resources. With increased personalised student access to social media, grasping cultural access therefore necessitates educators to interrogate 'situated knowledge practices' that students use to engage with social media for communication, expression and social action so that the educational context of its use can be preserved while simultaneously eroding the formal-informal space divides (Ng'ambi et al. 2016).

Czerniewicz and Brown's (2013) study demonstrated how PDS' technological habitus, itself shaped by their cultural capital, was a function of their social backgrounds characterised by limited access to and limited practices in relation to computers. However, these students also demonstrated diverse practices and widespread astute use of cell phones, suggesting their capacity to draw on cultural capital to enhance their academic pursuits.

\section{Mobile instant messaging for meaningful teaching and learning}

As this study explores the nexus among student mobile ownership, academic agency and networking capabilities and uptake of mobile phone applications, a review of literature on MIM is inevitable. A body of academic literature has explored the learning (Cetinkaya 2017; Gasaymeh 2017; Sayan 2016) and instructional potential of WhatsApp 
(Coleman \& O'Connor 2019; Gon \& Rawekar 2017). Gasaymeh (2017) interrogated university students' intended adoption of WhatsApp for educational purposes and their perceptions of its formal integration into their education practices. Despite the limited application of WhatsApp for learning purposes, students expressed positive feelings and intentions about its potential use for formal learning. They anticipated that its integration into education would be easy, fun and educationally useful. Cetinkaya (2017) explored the extent to which appropriation of WhatsApp could enhance success in education. The results revealed that while students affirmed the adoption of WhatsApp in their courses, the possibility of using messages with images to support unconscious learning, some students expressed negative sentiments about the redundancy and timing of some posts in groups.

The scoping review conducted by Coleman and O'Connor (2019) on the contribution of WhatsApp to supporting instruction in medical education revealed three strategies for WhatsApp use: its educational use within a pre-defined curriculum, its educational use without any curriculum and its non-educational use. Their integrated learning design framework for instruction, which drew on these three strategies, demonstrated WhatsApp can serve as an effective tool in medical instruction. Gon and Rawekar (2017) interrogated the effectiveness of using WhatsApp as a teaching tool in the natural sciences. In addition to continual learning provided via this platform and the continual availability of facilitators, students taught via this platform performed better than those taught using traditional lectures. The study, however, reported a deluge of messages, constraints of time and eye strains as technical challenges associated with using WhatsApp for instructional purposes.

In the South African context, Willemse (2015) examined the reflections of undergraduate nurses on WhatsApp use in improving primary health care education. Her findings revealed students' positive experiences of using the application; its capacity to facilitate the integration of clinical theory into practice; avail resources for test preparation; and provide opportunities for students to seek clarification. However, the challenges of its use for educational purposes included potential academic exclusion of students without the appropriate devices and quick depletion of battery power with prolonged use of the application. Gachago et al.'s (2015) research on lecturers' perspectives on the potential of WhatsApp to support teaching and learning revealed that this technology increased immediacy and connections across formal, informal and open distance learning contexts, facilitated reflection by students while simultaneously increasing their control and ownership of learning.

\section{Justification for using WhatsApp}

WhatsApp is a low-cost, instant messaging application that runs on web-enabled devices such as cell phones, personal digital assistants and laptops. On this web-based platform, users can form small groups of up to 11 members and exchange materials in various formats like audio, video, graphics and textual messages. Users may choose to interact using their mobile numbers as their personal IDs thus 'hiding' their real identities and may use pseudonyms or their authentic names.

There are multiple MIM platforms in South Africa such as WeChat, Mixit and Facebook Messenger. The WeChat platform's user base is predominantly in China, the headquarters of this company (Feng 2019), and is not popular in South Africa especially among university students judging from the small numbers on this platform. As both WhatsApp and Facebook Messenger are Facebook applications following Facebook.com's acquisition of WhatsApp platform, these platforms have comparable functionalities (friends' lists, cheap calls and group messaging) as well as subtle differences. For example, while many mobile phone operators may sell mobile phones pre-loaded with WhatsApp and Facebook Messenger depending on mobile packages they offer, WhatsApp remains more easily accessible and user-friendly for students irrespective of any phone's sophistication. This is because while Facebook Messenger is integrated with a Facebook user's profiles and requires them to log into their Facebook accounts to access it, WhatsApp is a stand-alone platform that allows users to connect to contacts already stored on their phones without any log-in requirements (Khillar 2018). Weinberg (2020) highlights that creating a user account is not required on WhatsApp because the user's phone number serves as his or her username. Furthermore, although Facebook messenger users must add their friends, all WhatsApp friends are automatically added by scanning the user's contact list for friends existing on her or his phone (Kumar 2016).

Apart from the convenience of accessing WhatsApp, the platform runs on any phone irrespective of its simplicity or sophistication. WhatsApp calls can be executed via second-generation (2G) and third-generation (3G) phones and on Wi-Fi including in locations with weak signals (Verma 2019). WhatsApp supports a myriad of platforms and devices ranging from smartphone platforms such as iOS, Android and Windows Phone to feature phone platforms such as Nokia S40 and S60 (WhatsApp 2020; Weinberg 2020). In contrast, Facebook messenger tends to be more effective on more sophisticated phones such as an Android operating system. Although Facebook messenger is ideal for conference calling involving up to 50 participants and WhatsApp only accommodates four people per conference call (Verma 2019), calling is not the ideal choice of cash-strapped students. Further, group work at our university often involves between three and seven students, and hence, WhatsApp is ideally suited for group collaboration as work commitments and logistical challenges often constrain all group members from participating at once. 
The greatest benefit of WhatsApp for students is that it requires less bandwidth to connect with little configuration compared with Facebook Messenger, a heavy bandwidth application that consumes much data and continually sends messages regardless of network strength (Khilla 2019). Access to data has remained a perennial issue in South African higher education judging from the \#data-must-fall-protests by university students, and the sub-optimal attempts by universities to provide free data for accessing learning resources to students further compound the challenge. Although Facebook Messenger is more sophisticated in loading multiple pictures, conducting conference calls and using colour gradients to show the mood of interactants, these features are more bandwidth-intensive and hence are not popular among students. Moreover, WhatsApp messages are protected by end-to-end encryption by default, implying that only authorised interactants can view messages exclusively - thereby guaranteeing more privacy. This can be contrasted with Facebook Messenger where encryption must be activated to work (Khillar 2018).

\section{Methodology Case study paradigms}

Unlike other methodological designs (e.g. quantitative surveys) that exhibit a clear paradigmatic orientation, the practical versatility of the agnostic approach of case studies (Harrison et al. 2017) implies that 'they cannot be assigned to a fixed ontological, epistemological or methodological position' (Rosenberg \& Yates 2007:447). Case studies therefore can fit multiple epistemological and methodological positions such as quantitative, qualitative and mixed approaches. In recognition of this complexity, the researchers had a choice to approach case study research from a realist (i.e. positivist) perspective or a relativist (i.e. interpretivist) perspective. Drawing on a realist perspective would mean that the researchers ascribe to the existence of a single reality, which is independent of them, can be apprehended, studied and measured (Harrison et al. 2017). A post-positivist approach focusses on conducting empirical inquiry drawing on the maintaining objectivity to allow for and the generalisability of results (Ellingson 2011; Yin 2014).

Post-positivist employs science as a mode of inquiry to understand the nature of reality and utilises multiple data collection methods as an acknowledgement of the imperfection of all tools of measurements, to arrive at the 'truth' (Harrison et al. 2017). Although we conceded that data source triangulation allows the capturing of the multi-faceted nature of reality, we questioned the claim that using multiple sources would increase objectivity because as social beings, individuals are subjective by nature. We submitted that researchers and students employ their subjective experiences to make sense of their interactions and to understand any given phenomenon in context. The researchers also questioned Yin's (2014) pre-occupation with hypothesis testing as a way of generating alternative explanations for reality and adoption of multiple case studies to allow for generalisability of results. Although post-positivists conceive a case study as a naturalistic study, they employ scientific strategies such as allowing the investigator to exert control over and manipulate the variable(s) of interest (Crowe et al. 2011) to get to the bottom of the issue under investigation. As case studies cannot be disentangled from their context, we submitted that meaning making and use of experiences are context-dependent and would vary if contexts of their application change. For that reason, the extent of generalisation of case studies using a post-positivist perspective would be limited.

Our research identified with an interpretivist perspective that emphasises the existence of multiple realities and meanings, which depend on and are co-created by the researcher and participants involved in the research (Lincoln, Lynham \& Guba 2011). To the extent that case studies strive to generate for the researcher an in-depth, holistic, multi-faceted understanding of a complex issue in its real-life context (Crowe et al. 2011), the deployment of interpretation and inductive reasoning would be more reasonable than seeking to generalise findings. The research was therefore informed by a constructivist and interpretivist orientation, which strives to discover meaning and understanding of experiences in context (Harrison et al. 2017; Stake 2006). Adopting an interpretive and constructivist perspective allows the researcher to look at the phenomenon in context (Farquhar 2012), enter the scene with a sincere interest in learning how (participants) function in ordinary pursuits and milieus and with a willingness to put aside many presumptions while they learn (Stake 1995). Stake (2006) emphasises an interpretivist role where realities are multiple and subjective, dependent on the meanings and understanding of those directly involved in its construction.

\section{Research design}

The research adopted a case study approach. A case study is an intensive, systematic investigation of a single individual, group, community or some other unit in which the researcher examines in-depth data relating to several variables (Woods \& Calanzaro 1980). The case of student interaction with the facilitator and lecturer was examined in-depth to get a closer glimpse of how students' access to mobile devices shaped their capabilities as social agents involved in social acts (i.e. 'doings' such as posting texts, photos and videos and 'beings' - their sense of themselves), and how their ownership of mobiles shaped their agency in co-creating educational resources. The variables examined are accessibility to mobiles, capabilities, student agency and co-creation of resources.

Fouchè and Schurink (2011) suggest that case studies allow researchers to understand the meaning that research participants assign to their life experiences by immersing themselves in the activities of these participants to obtain an intimate familiarity with their social worlds. The approach was therefore qualitative to the extent that it examined lecturer-student, facilitator-student 
and peer-based interactions on WhatsApp including students' reflections of their WhatsApp academic activities via their personal blogs. In case study research, complex phenomena are examined in their natural setting to provide a holistic understanding of them (Yin 2003). Students' social acts of posting different learning resources were examined to systematically dissect and understand the contribution of mobile access to shaping students' capabilities including how accessing mobiles shaped their agency in creating learning resources collaboratively.

\section{The e-research strategy}

The study participants comprised 72 black African human resource management (HRM) students at a university of technology in South Africa. As this university's admission policy considers all black African students as 'historically disadvantaged', we classified this group of students in similar terms. To further compound this historical disadvantage, most of these students stayed off campus, which limited their access to institutional ICT networks, library resources and university-based peer networks. This meant that these students only accessed these learning resources on campus during the day and had limited access at home because of the high cost of Internet data plans. Although these students accessed the university LMS during their contact hours, access was also limited after hours because of connectivity problems off campus.

The rationale for using WhatsApp in the programme was to expose these geographically distributed HRM students to the research concepts, processes and techniques as well as render them first-hand experiences of using mobile technology to support their collaborative learning and cocreation of knowledge. To establish the extent of students' familiarity and usage of WhatsApp, the educator inquired about the number of students who had used it for social interaction consistently for more than 3 months and a majority claimed they had. Although most students had some experience of social uses of WhatsApp, a few had used it for academic purposes, thereby necessitating additional educator support.

Although most participants already had WhatsApp downloaded on their mobile phones, the educator encouraged all participants to have this mobile application active on their mobile phones. The 72 participants were divided into seven clusters of up to 11 participants per cluster and encouraged to join their respective clusters on WhatsApp. Although no formal assessment and marks were awarded for online participation, students were expected to engage in the following tasks: respond to one research methods question that the lecturer sent to all clusters when they interacted after hours, use WhatsApp to post, respond to and discuss a research methods question from peers and contribute to the development of research knowledge through collaborative learning in groups.
As the study focussed on students' use of WhatsApp and agentive experiences thereof, non-participants were naturally excluded from the study although no sanctions were imposed from non-participation. In addition to the lecturer, an external researcher from another university served as the online facilitator. The facilitator posed questions about research concepts and processes taught in class by the lecturer and responded to participant queries via WhatsApp. Prior to this, the lecturer had introduced the online facilitator to students in a face-to-face session and notified them of his or her availability between 18:00 and 20:00 to engage with them on their research methods challenges.

Besides consulting with the lecturer and the online facilitator, participants also engaged with peers on research processes via WhatsApp after lectures. Student-facilitator, student-lecturer and peer-based interactions focussed on students' understanding of research processes such as refinement of research topics, tenets of a good literature review, research design and methodological issues and advice on complex research processes. Student interactions lasted for a semester (6 months). Most postings were on research processes especially research design issues, choices of research topics and descriptions of good literature reviews. The lecturer also clarified and reinforced in class the issues discussed in all clusters online.

\section{Blog reflections}

To corroborate the evidence of 'being' and 'doing' in WhatsApp collaborative learning, participants were also expected to create personal blogs and reflect individually on their learning via WhatsApp. They were encouraged to reflect on how their online access to learning resources impacted their engagement capabilities including potential challenges of accessing WhatsApp. The blogging commenced 2 months after participants had started interacting on WhatsApp and enabled them to individually reflect on their WhatsApp collective engagements. The personal blogs were in the institutional LMS, Blackboard. Of all participants, only 19 of them (11 females, 8 males) made one to three blog entries each. A total of 32 blog entries were recorded. Entries focussed on WhatsApp's communicative power in relation to research processes, the value of the academic support the facilitator provided, WhatsApp's capacity to break the 'transactional distance' (Moore 1993:22) between participants, and access to the facilitator's advice during group assignments after hours. The tasks related to asking peers, the educator and facilitator research methods questions, responding to questions and contributing to collaborative production of research knowledge.

\section{Sampling and participant selection}

To the extent that all students despite their social circumstances were enrolled for the HRM course, it can be argued that these participants were self-selected by virtue of being members of this course. However, it can also be 
argued that as all students who participated were expected to be WhatsApp participants, purposive sampling was employed as participants were expected to have experience of interactions and collaborative engagement with peers during the co-creation of knowledge. As the study focus was on co-creation of knowledge drawing on a social media platform, only students who had participated via the platform were deemed to have developed some knowledge of and experience in using the platform for learning.

\section{Data analysis}

Although capabilities concepts (e.g. functionings, capabilities and freedoms) were drawn upon to provide a broad framework against which categories could be interpreted, the categories themselves were drawn from raw data using inductive analysis (see Table 1). Thematic analysis was used in the extraction of categories from raw data. Thematic analysis involves repeated reading and analysis of texts and the identification of key themes across diverse data (Pimmer \& Rambe 2018). The process involved gleaning through the WhatsApp and blog data entries to gain a broad grasp of their contents. The second reading emphasised identifying relevant texts from the raw data. The next step involved coding and development of categories, guided by texts that frequently emerged from the raw data. It is important to emphasise that the focus here was not only on the texts exchanged, but also the broader context and milieu in which they emerged. Categories were derived from raw data inductively even though the main concepts that framed the overall analysis were deductively derived from the reading of capabilities framework literature. In other words, while the analysis of texts was inductive, the main concepts were applied in a deductive manner (Pimmer \& Rambe 2018) (see Table 1).

\section{Findings}

The tenets of the theoretical framework were drawn upon to interpret the research findings. These tenets include functionings, capabilities and freedoms. These tenets were informed by the research questions that focussed on the:

- influence of ownership of mobile phones on student agency over co-creation of learning of learning resources;
- impact of mobile access on students' capabilities as agents involved in 'being' and 'doing'.

\section{Functionings}

Functionings describe the various endowments including entitlements that human beings value possessing or becoming (or being). These acquisitions can be material (wealth, higher education, health) or non-material (skills, knowledge, capabilities, technological networks). Student functionings (what they valued 'doing' or 'being') therefore involved exchanging specific information (e.g. conducting credible data analyses or literature reviews), (see Figure 2 and Figure 4) reminding each other of upcoming academic tasks and giving suggestions on solving them. To this effect, they valued becoming information givers, information seekers, knowledge brokers and informal mentors to their academically challenged peers. They cherished becoming contributors to knowledge through their responses to online facilitator's question on how to conduct a credible literature review:

Other student functionings were related to their yearnings about redressing information asymmetries that plagued their academic institution. In poorly resourced institutions, off campus students often struggled to access library books and journals after hours. Students' desire to widen mobile access to educational materials is embodied in the suggestion (see Figure 1).

This resonates with student functionings on improving personalised access to academic resources for all students. Students also reflected via Blackboard blogs on the academic value of multiple accesses to educational materials, open communication and group sharing of content:

'I have been using a Blackberry phone but was not familiar with WhatsApp. Now I enjoy using it as a communication tool. It helps with the Research Methodology in that the questions being asked and answered, we all share it as groups [...].' (Female student, Blog post, June 2018)

'WhatsApp is a smart way of learning with our peers as we can share ideas and openly question each other's views. WhatsApp allows $[u s]$ to exchange messages without having to pay much. It allows us to understand the lecturer's expectations of us.' (Male student, Blog post, July 2018)

TABLE 1: An analysis of original WhatsApp and Blog posts using Sen's capabilities approach.

\begin{tabular}{|c|c|c|c|}
\hline $\begin{array}{l}\text { Capabilities approach-based } \\
\text { themes }\end{array}$ & Categories & Original artefacts: WhatsApp or Blogs & Researchers' comments \\
\hline Functioning & Academic networking & $\begin{array}{l}\text { 'I enjoy using it as a communication tool. It helps with the Research } \\
\text { Methodology in that questions are being asked and answered, we all } \\
\text { share it as groups.' (a student's blog postings) }\end{array}$ & $\begin{array}{l}\text { WhatsApp is valued as a transactional } \\
\text { platform. }\end{array}$ \\
\hline Capabilities & Collaborative engagement & $\begin{array}{l}\text { 'My advice will pls ensure dat u investigate acrding to ur research topic } \\
\text { en ur literature review in terms of guidance dat Dr Chris uploaded in } \\
\text { ethutho-ur topic will guide of what need to be done [...].' (a student's } \\
\text { advice on WhatsApp) }\end{array}$ & $\begin{array}{l}\text { Peer advice on how to develop a } \\
\text { credible literature review }\end{array}$ \\
\hline- & Negative freedom & $\begin{array}{l}\text { 'There is no internet access. Can those in offices make copies for us if } \\
\text { they log on earlier please.' (a student's posting on WhatsApp) }\end{array}$ & $\begin{array}{l}\text { Hard copies complement online access } \\
\text { due to erratic networks. }\end{array}$ \\
\hline
\end{tabular}




\section{SUGGESTION: Issue students with} tablets e.g. iPad with enrollment. This could be pre-loaded with all study guides and in collaboration with Van Schaik even with the various prescribed books via E-books. Access could be given to the intranet via Wi-Fi while on campus and tests could be written electronically in class without the need to use the computer lab. There are some tertiary institutions like Boston City Campus using this method already.

FIGURE 1: Example 1 of student functioning.

\section{Pls download some joumals based on ur research topic and look at de features of literature review frm those joumals as per topic - i think dat route wil clear some misconceptions that whoever u re having. 20:34}

FIGURE 2: Example 2 of student functioning.

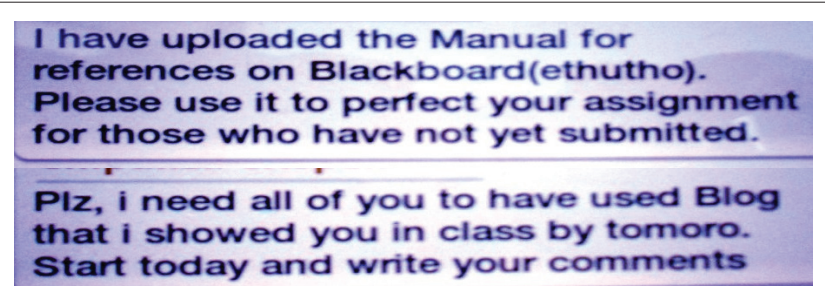

FIGURE 3: Example of lecturer's functioning.

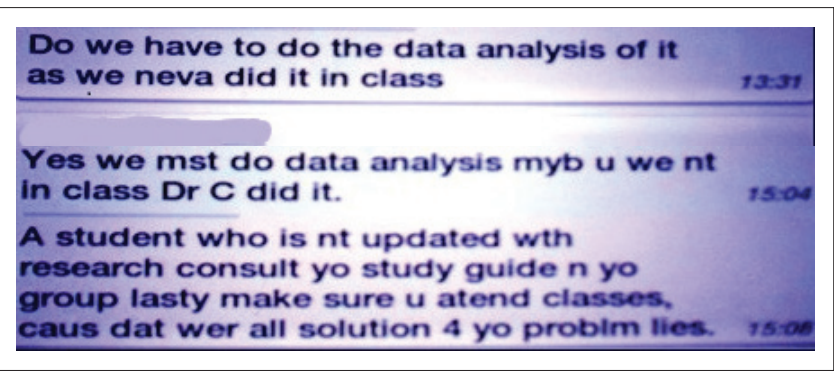

FIGURE 4: Example of students' sharing of academic information.

These blog posts are indicative of the communicative, critical questioning and collaborative sharing culture on WhatsApp. Student functionings played out in their praising of familiar technologies that enhanced public expression and fostered collaborative learning communities.

The lecturer's functionings were entrenching students in appropriate academic conventions and practices that enabled them to: (1) become emerging, informed contributors to their field, (2) engage with educational materials to execute assignments effectively (see Figure 3) and (3) improve students' academic networking based on learning tasks. Thus, she or he occasionally provided announcements and additional materials on the institutional LMS to ensure effective execution of academic tasks by students.

Therefore, the lecturer and online facilitator's support interfaced with peer-based networking to ensure collective generation of resources and integrated online learning.

\section{Access to academic networking}

The appropriation of WhatsApp breached the psychological barriers among students by enhancing peer-based academic networking among those with different academic abilities. The use of WhatsApp also bridged students' physical distance from institutional resources and breached transactional distance between peers caused by lack of physical contact and limited communicative competence. Open conversations via WhatsApp enhanced students' sharing of academic information as shown in Figure 4 .

The peer response to the student's question on data analysis, which highlighted the need to consult the study guide, track conversations in one's WhatsApp group and to attend classes regularly, highlights the potential of WhatsApp interaction to support students' context-free access to peer-based educational resources and artefacts (questions, responses, elaborations and critique) anywhere, anytime.

\section{Capabilities}

Capacities embody human commitment to purposive actions and enactment of particular identities. They constitute expressions of human agency and free choice within environmental enablers and constraints. Capabilities included role play in collectively generated resources and critical questioning of postings. These roles are discussed in sub-sections on role play and critical questioning below.

\section{Role play in collaborative engagement}

Capabilities were instantiated in peer-based sharing of advice on the execution of academic tasks. Students exploited WhatsApp to assist peers in dealing with problematic concepts and tasks the lecturer and the online facilitator assigned to them. Consequently, some students assumed 'advisory' roles on WhatsApp:

'My advice will be that please ensure that you investigate literature in line with your research topic [...] you can use existing literature and be able to expand your findings [...].' (Student Peer, Whatsapp post, May 2018)

Such additional responsibilities and serendipitous learning illustrate transformative uses of WhatsApp as students transcended roles prescribed by their educators of information generation, knowledge sharing and group collaboration on academic tasks. These capabilities are expressions of student agency and knowledge construction through complex processes of intuitive learning. 


\section{Critical questioning}

The lecturer's capabilities involved his or her intentional modelling of learning tasks through critical questioning. He or she occasionally tested students' understanding of research concepts by posing questions on complex, but often taken-for-granted concepts:

'What is the difference between concepts and constructs in research?' (Lecturer, Whatsapp post, April 2018)

'Constructs are concrete forms of behaviour [...] concepts are collection of meanings associated with events [...].' (Female student, Whatsapp post, April 2018)

Students also extended their knowledge of technologymediated interaction beyond WhatsApp by using it to discuss features of other learning platforms like the institutional LMS (Blackboard):

'Hi guys how do I open the test page [...] where do I click to get it?' (Male student, Whatsapp post, March 2018)

'Assessment on your left side menu when you open ethutho.' (Student peer, Whatsapp post, March 2018)

As such, WhatsApp presented an information gateway linking students to other ICT platforms, extending practical knowledge of their interfaces. As capabilities are in Sen's (1985b) view outcome based and relate to authentic activities accomplished, accessing other platforms and extending knowledge all suggest the productive nature of capabilities. Given that capabilities comprise a set of functionings from which a person can choose (Sen 1987b), it can be argued that WhatsApp enhanced students' ability to choose among different roles and identities at a time: engaging in dialogue with the educator, 'being' an inquirer and 'being' a respondent as evidenced by the interactions.

\section{Freedoms}

Freedom encapsulates an individual's actual ability to achieve her or his functionings (i.e. endowments and acquisitions she or he values). For Sen (1987b, 1992), freedom finds expression in choices about possible actions and achievements of those things that individuals value (positive freedom) and the absence of constraints that undermine the achievement of functionings (negative freedom). Both positive freedom and the eradication of impediments to realising functionings (negative freedom) are discussed in sections on freedom.

\section{Positive freedom}

WhatsApp presented students with opportunities to make informed choices (freedom) about academic commitments they valued such as sharing of knowledge of complex concepts and routine academic practices. It allowed students to 'get instant positive feedback from educators without having to commute to campus' (Male student, Blog post, July 2018) and extend their consultative base by 'connecting to an attentive, cohesive group rather than wait for educators' responses' (Male student, Blog post, June 2018). These acquisitions and entitlements were quintessential for off-campus students with limited access to libraries after hours and limited Internet connectivity. Similarly, the lecturer employed WhatsApp for academic planning and scheduling of tasks, which students prepared for before lectures:

'Dear students. Remember tomorrow Tuesday (7 August) your group is presenting [...] put your presentation on power point [...].' (Lecturer, Whatsapp post, August 2018)

'I have uploaded the manual for references on Blackboard [...] use this as a guide for your assignments.' (Lecturer, Whatsapp post, July 2018)

WhatsApp became the lecturer's strategic tool for initiating student understanding of other learning platforms.

Blog comments illustrated that WhatsApp enhanced students' flexible learning by broadening opportunities for academic questioning at their convenience:

'WatsApp has been a great help because I don't have to wait for a class to ask a question, I can ask anytime, anywhere.' (Female student, Blog post, July 2018)

WhatsApp also enhanced mobile learning for off-campus students who had limited access to institutional networks after hours (see student blog entry under positive freedom in Table 1). As such, their remote location did not hinder their networked access to learning resources.

\section{Negative freedom}

Negative freedom describes the removal of impediments to the realisation of capabilities. However, eradicating these barriers and constraints to the attainment of capabilities constitutes an essential but inadequate precondition for the full enjoyment of one's capabilities. It merely provides a starting point for the pursuit of positive freedoms. One manifestation of negative freedom was students' limited access to Internet networks, which prevented them from accessing WhatsApp and Blackboardgenerated resources:

'There is no internet access [...] can those in offices make copies for us if they are logged on [...].' (Male student, Whatsapp post, April 2018)

'Dr, this test switches off on its own [...] after 19 minutes [...] even though one has not yet saved.' (Female student, Whatsapp post, April 2018)

Students' blog entries on the removal of constraints to learning and access to educational material via WhatsApp affirmed the application's potential to reduce transactional distance between students:

'Whatsapp group is very convenient especially when we are doing assignments. It shortens the distances between us all and helps us get information quickly from other students and the lecturer.' (Male student, Blog post, June 2018) 
Blog comments also illustrated that WhatsApp afforded students' free expression in a friendly non-classroom environment thus ameliorating non-participatory constraints.

\section{Ethical consideration}

Ethical clearance was obtained from the Faculty of Management Sciences Research Ethics Committee - Central University of Technology, Free State (Ethical Clearance Number: PCD/2019, August 2019).

\section{Discussion}

The discussion is presented consistent with the research questions, by using the evidence presented in the 'Results' section.

\section{Access and productive use of collectively generated resources}

The results of the study provide support for peer-based collaborative engagement and hierarchical academic networking through student clusters' access to knowledge, the lecturer and the facilitator. The WhatsApp platform created an ambient, informal 'rendezvous' (Rambe \& $\mathrm{Ng}^{\prime}$ ambi 2014) for student expression of their choices about information sources and academic resources they preferred. Student agency manifested in their conscious decisions to appropriate WhatsApp to breach physical and cognitive disconnects from institutional resources and face-to-face conversations after hours. This breaching manifested in their contributions to online facilitator's questions, communication of academic routines and sharing of peergenerated advice. This demonstrates that access to WhatsApp-enabled mobile phones activated and accentuated their learning capabilities as they became more engaged in their 'doings' - academic activities they valued and cherished. At best, WhatsApp provided a unique way of connecting to peers that offered real opportunities to develop meaningful learning communities and enable negotiation of their learning journey (Madge et al. 2019).

Moreover, the use of WhatsApp enabled students to traverse and cross boundaries of their 'beings' - their identities as historically disadvantaged students with limited access to learning opportunities after hours and in their geographical enclaves. Therefore, the academic exchanges among student clusters and with their educators and facilitators pointed to enablement of students' discursive capabilities and breaching of knowledge enclaves based on social geography and ethnic backgrounds. This resonates with Madge et al.'s (2019) claim that in South Africa, the interweaving of access to technological infrastructure with socio-economic differences found expression in students', who are from disadvantaged backgrounds, perception of WhatsApp as a unique opportunity to engage collaboratively and negotiate their academic identities. Therefore, the engagement capabilities (afforded by technology) would have asserted among these students the freedom to attain their well-being (Robeyns 2011). This is partly because such students often emerged from historically disadvantaged high schools, which inadequately prepared these students for university education - therefore, WhatsApp could have augmented their academic deficiencies. As Pachler, Cook and Bachmair (2010) observe, student agency is tied to the effective appropriation of cultural tools, interrelationships between informal learning settings and mobile media usage including enactment of practices that improve authentic value of resources students bring into learning contexts.

The study also sought to address how ownership of WhatsApp-enabled phones enhanced student agency to co-create learning resources. With WhatsApp usage, academic agency also manifested in problem solving and serendipitous learning through sharing of academically related information (due dates for assignments and research methods readings), which unfolded at students' own pace and time. With the ubiquity of mobile devices, student agency now therefore manifests in finding information rather than merely possessing it, in new forms of (academic) performance and new ways of accessing them (Traxler 2007). Literature concurs with these findings by arguing that, in the knowledge society, the important pedagogical approaches that engender student agency are providing variety in learning activities, offering opportunities for students to learn at their own pace, encouraging collaborative work and focussing on problem solving (Ng'ambi, Bozalek \& Gachago 2013; Voogt et al. 2011). Information sharing through WhatsApp enabled the development of a complex hierarchy of individual student roles: knowledge brokers, knowledge seekers, information givers and informal mentors.

\section{Redressing information asymmetries}

It is critical to emphasise that the study examined why despite student access to mobile phones, and general understanding of the affordances thereof (i.e. WhatsApp), knowledge-sharing practice could not be fostered using WhatsApp. An assortment of factors seemed to explain this phenomenon: absence of institutional learning materials to draw on during conversations on WhatsApp, students' limited knowledge on how to use collaborative cloud-based technologies in academically meaningful ways, limited availability of high-end mobile phones with enhanced functionalities and linguistic challenges to engage collaboratively in groups. While appreciating the agency that WhatsApp usage activated, it also exposed subtle forms of the digital divide such as off-campus students' limited access to learning materials (books, journals) availed in institutional libraries. These broad inequalities are symptomatic of the broader and longstanding inequalities that South Africa continues to grapple with in the contemporary period despite the end of colonialism and apartheid (Letseka, Letseka \& Pitsoe 2018). The university where this research was conducted is situated in an urban setting with unlimited access to the Internet even though most of its off-campus 
students come from economically deprived settlements (formerly called 'Bantustan locations') with limited access to modern amenities created by legacy of apartheid. As such, economic apartheid is reproduced in economic enclaves with asymmetric access to learning resources and the Internet connectivity.

To address this anomaly, some students suggested that universities should provide iPads preloaded with electronic books to increase their access to educational materials after hours. Recently, the South African government acknowledged the prevalence of these asymmetrical economic geographies, which necessitated the provision of Internet data plans and laptops to under-privileged students by higher educational institutions during COVID-19-induced lockdown (Nzimande 2020). Although WhatsApp academic conversations contributed to redressing information asymmetries between off- and on-campus students, it also highlighted the need for complementary measures for the provision of academic resources. Therefore, students' exposure to multiple learning platforms such as LMS and WhatsApp, which heightened open communication, could be critiqued for overlooking differential access to learning and knowledge networks (Czerniewicz \& Brown 2005). Thus, claims about WhatsApp's capacity to sufficiently breach information asymmetries should take cognisance of evidence on varied access to high-end mobile phones, asymmetries in ICT skills and general underpreparedness among at-risk students. In South Africa HEIs, mobile phone ownership, particularly smart phones, cannot be assumed to be equal and balanced (Czerniewicz 2009), and digital strangers remain a challenge in tertiary contexts where students' asymmetrical access to educational technologies persists on and off campus (Czerniewicz \& Brown 2013).

\section{Supported role play}

Access to WhatsApp shaped student-networked capabilities in online learning communities by empowering them to assume alternative roles to those assigned by their educators. For instance, WhatsApp created a viable technological context for students' role play in problem solving and advising peers on complex academic matters. These supplementary roles suggest that WhatsApp created a quasiinformal learning context that students exploited for selfdiscovery and intuitive learning. Webb (2013) suggests that introducing new technology enhances pedagogical demands, enables purposive sharing of roles between educators and students and engenders a learning culture that supports interaction.

An unintended effect of accessing mobile applications on students' capabilities was the transference of technology usability skills. The educator's strategic modelling of tasks (e.g. task-focussed discussions, critical problem solving, research-based consultations) enabled students to explore the affordances of WhatsApp tools and interfaces in conjunction with other institutionally sanctioned technologies such as Blackboard LMS. Our findings dovetail with Makoe (2010) who found that students' use of MXit enhanced the understanding and use of other exclusive online learning communities. MXit is a popular South African instant messaging platform that runs on mobile devices and allows users (predominantly youths) to form and exchange social networks, messages and other mobile resources of their choice.

\section{Negative freedom}

The findings also exposed other variations of the digital divide such as challenges of Internet connectivity because of power cuts and erratic networks, which limited access to educational materials during work hours and after hours. The articulation of these challenges demonstrates WhatsApp's capacity to expose the 'networked divide', which describes stratified access to hardware, software, applications, networks and devices, which produce classes of winners and losers of the information society (Fuchs \& Horak 2008). These network asymmetries foreclose opportunities for students to make meaningful technologymediated educational decisions. Our findings describe conditions of network failure, limited connectivity beyond campus and limited educational opportunities in the absence of complementary technologies - which are all expressions of negative freedom.

Our findings transcend a 'technicist' conception of the digital divide, which over-emphasises access to personal computers, Internet networks and technological infrastructure but ignores complex, access variations in perceivably homogenous groups (intra-group dynamics) on and off campus. Although on-campus access was relatively equal, variations persisted beyond campus after hours. This resonates with the view that technological binaries should consider effective use of technologies and quality of access that have become pertinent in an increasingly interconnected world (Mutula 2008).

\section{Study implications}

Our study demonstrates that student-centred constructivist ways of generating knowledge are critical to students' effective engagement with peers on WhatsApp. Student agency found expression in their engagement with the lecturer and facilitator on academic issues. The heightened participation of students suggests that they valued online facilitation of discussions by academic educators, pointing to the importance of sustained moderation by educators. Online facilitation, however, should embrace more than questionbased consultation to include assisting students in more scholarly application of WhatsApp to research processes such as academic referencing, meta-learning skills such as academic research writing and logical argumentation in groups. Ng'ambi et al. (2013) recommend a framework for educator online facilitation of authentic learning activities that foregrounds inter alia: group-based sharing of web applications, collaborative working on documents and 
following opinion leaders in students' fields of research to access current articles and blog posts.

Drawing on Sen's (1985b) capabilities, we descried the different choices of actions that educators and students adopted and identities they assumed across different educational contexts. The educator's capabilities manifested in strategic scaffolding of students in research by posing critical questions that required students to reflect and engage with concepts and constructs. Students' limited engagement with these concepts provides justification for aligning educational resources availed in class with WhatsApp tasks and collaborative discussions to ensure more authentic, meaningful learning. Students' capabilities were embodied in their academic identities as networked collaborators who transacted with their academic community (peers, lecturer and facilitator) on WhatsApp. They also assumed super-tutor roles of mentoring peers in complex problem solving and serendipitous learning such as exploring the affordances of the LMSs. Such unintended effects of WhatsApp usage suggest that more integration of LMS and WhatsApp pedagogical activities should be promoted through shifting focus from learning with these technologies to learning from them (i.e. foregrounding transformative adoption of tools so that pedagogical tasks or activities can be better executed).

Drawing on Sen's (1999) conception of functionings as the various things humans value 'being' or 'doing', we highlighted that students valued seeking information, giving information, communicating and brokering knowledge and serving as informal mentors to peers. The dominance of information exchange (information seeking and giving) suggests that educators' pedagogical activities could benefit from emphasising this capability to create the conversation threshold necessary for progressing to more complex tasks (e.g. more complex problem solving, argumentation). The educators' functionings were embodied in their valuing of critical questioning, contributing factual information and knowledge during scaffolding, foregrounding task-focussed academic networking, individual reflection and collaborative networking. There was, however, no evidence of deep philosophical conversations on research processes among students, suggesting that the discussion of concepts and constructs needed to target more cognitively demanding discourses on research philosophy to improve the academic usefulness of WhatsApp.

Effective access to learning resources via WhatsApp and online facilitation of learning tasks was often disrupted by students' asymmetrical access to mobile learning networks. Increasing wireless hotspots on campus could support universal access to educational resources on campus via mobile devices. University administrators should also lobby Internet service providers to subsidise mobile data provision for academic activities via local cellular networks or reduce communication costs by incentivising mobile network operators that invest in upgrading of university mobile networks.

\section{Conclusion}

This study investigated the potential of WhatsApp to support student academic agency particularly their access and appropriation of collectively generated educational resources. Findings suggest the capacity of WhatsApp to heighten students' access to learning resources through collaborative dialogue and engagement between peers (student-peer interaction) and collectives (lecturerstudent and student-facilitator). To explore geographically remote students' access and productive use of mobile learning resources in resource-constrained environments, Sen's capabilities framework, which analyses technology users' capabilities, functionings and freedoms, was drawn upon as an interpretive and analytical framework.

Mindful of the resource-constrained context marked by asymmetrical access to learning networks, slow Internet connectivity and unreliable networks, student agency and strategic use of their capabilities and functionings were critical to optimise access and use of mobile learning resources. Self-initiative through strategic engagement in peer-generated networks and heightened participation in learning activities when online learning networks were available became ideal strategies for academic survival. As such, Sen's (1987b) conceptions of positive and negative freedom constituted useful lenses for leveraging students' capabilities (peer-based collaboration, academic networking, problem solving) and ameliorating the constraints and risks associated with the use of emerging technologies in resourceconstrained contexts.

In view of these results, productive mobile media pedagogy should encapsulate an integrated pedagogical strategy that assesses the situated context of mobile media innovation (enablers of effective adoption of MIM and barriers to MIMmediated learning) and aligns it consistently with pedagogical activities, students' capabilities, learning needs and preferences. Consistent with Sen's (1992) preoccupation with capabilities, effecting this strategy demands assessing the available stock of students' functionings and MIMmediated capabilities and aligning them with educators' scaffolding techniques albeit variations in access to networks and resources. Lastly, student clusters need to adapt to the nature and complexity of tasks given to ensure the authentic generation of collaborative resources.

Overall, WhatsApp served as an important vehicle for bridging access to learning resources, a platform for providing peer-based and hierarchical support, for leveraging on-task behaviour and promoting meaningful context-free learning. These technology affordances were deeply implicated in several negative freedoms, which impeded mobile access such as students' limited access to Web-enabled mobile phones, erratic network connectivity and cost of data plans. Consequently, any interventions 
aimed at redressing these access issues should be located at the interface of timeous pedagogical delivery, technological affordances and the broader social constraints of technological applications.

\section{Acknowledgements}

The authors would like to thank all the students who participated in the study, as well as the institution which granted permission for the study.

\section{Competing interests}

The authors declare that no competing interest exists.

\section{Authors' contributions}

Conceptualisation was performed by P.R., C.C. focussed on the literature and data collection a bit and D.N. helped in the write-up, language editing and final presentation of the article.

\section{Funding information}

This research received no grant from any funding agency in the public, commercial or non-profit sectors.

\section{Data availability statement}

Data sharing is applicable - new data were created and analysed, and therefore, can be shared.

\section{Disclaimer}

The views and opinions expressed in this article are those of the authors and do not necessarily reflect the official policy of any affiliated agency of the authors.

\section{References}

Alkire, S., 2005, 'Why the capability approach?', Journal of Human Development 6(1), 115-133. https://doi.org/10.1080/146498805200034275

Archer, M., 2010, 'Routine, reflexivity, and realism', Sociological Theory 28(3), 272-303. https://doi.org/10.1111/j.1467-9558.2010.01375.x

Bandura, A., 1977, 'Self-efficacy: Toward a unifying theory of behavioural change' Psychological Review 84(2), 191-215. https://doi.org/10.1037/0033-295X.84.2.191

Bozalek, V., Ng'ambi, D., Wood, D., Herrington, J. Hardman \& Amory, A. (eds.), 2014 'An introduction', in Activity theory, authentic learning, and emerging technologies: Southern perspectives in higher education, Routledge, London. https://doi. org/10.4324/9781315771823

Bozalek, V., Garraway, J. \& McKenna, S. (eds.), 2011, 'Introduction', in S. McKenna (eds.), Case studies of epistemological access in foundation / extended curriculum programme studies in South Africa, pp. 1-5, Fundani, CPUT.

Cetinkaya, L., 2017, 'The impact of Whatsapp use on success in education process', International Review of Research in Open and Distributed Learning 18(7), 59-74. https://doi.org/10.19173/irrodl.v18i7.3279

Coleman, E. \& O'Connor, E., 2019, 'The role of WhatsApp ${ }^{\circledR}$ in medical education; a scoping review and instructional design model', BMC Medical Education 19, 279. scoping review and instructional design mode',
https://doi.org/10.1186/s12909-019-1706-8

Crowe, S., Cresswell, K., Robertson, A., Huby, G., Avery, A. \& Sheikh, A., 2011, 'The case study approach', BMC Medical Research Methodology 11(100), 1-9. https://

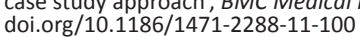

Czerniewicz, L. \& Brown, C., 2013, 'The habitus of digital 'strangers' in higher education', British Journal of Educational Technology 44(1), 44-53. https://doi. org/10.1111/j.1467-8535.2012.01281.x

Czerniewicz, L., 2009, Cell phones and Sakai - Increasing access for all, Paper read at Sakai 2009, Boston, MA, July 8-10.

Czerniewicz, C. \& Brown, C., 2005, 'Access to ICT for teaching and learning: From single artefact to inter-related resources', International Journal of Education and Development using Information and Communication Technology 1(2), viewed 12 August 2013, from https://ijedict.dec.uwi.edu/viewarticle. php?id=38.
Ellingson, L., 2011, 'Analysis and representation across a continuum', in N.K. Denzin \& Y.S. Lincoln (eds.), The Sage handbook of qualitative research, 4th edn. pp. 595-610, Sage, Thousand Oaks, CA.

Farquhar, J.D., 2012, 'What is case study research?', in J.D. Farquhar (ed.), Case study research for business, pp. 3-14, Sage, London.

Feng, E., 2019, China intercepts WeChat texts from U.S. and abroad, researchers say, NPR Headquarters, Washington, DC, viewed 19 March 2019, https://www.npr org/2019/08/29/751116338/china-intercepts-wechat-texts-from-u-s-andabroad-researcher-says.

Fuchs, C. \& Horak, E., 2008, 'Africa and the digital divide', Telematics and Informatics $25(2)$, 99-116, viewed 13 October 2008, from https://doi.org/10.1016/j. tele.2006.06.004.

Fouchè, C. \& Schurink, W., 2011, 'Qualitative research de-signs', in A. De Vos, H., Strydom, C. Fouche \& C. Delport (eds.), Research at grassroots: For the social and human service professions, pp. 307-327, Van Schaik Publishers, Pretoria.

Gachago, D., Strydom, S., Hanekom, P., Simons, S. \& Walters, S., 2015, 'Crossing boundaries: Lecturers' perspectives on the use of WhatsApp to support teaching and learning in higher education', Progressio: South African Journal for Open and Distance Learning Practice 37(1). https://doi.org/10.25159/0256-8853/579

Gasaymeh, A.-M., 2017, 'University students' use of WhatsApp and their perceptions regarding its possible integration into their education', Global Journal of Computer Science and Technology 17(1), 1-11.

Gon, S. \& Rawekar, A., 2017, 'Effectivity of e-learning through WhatsApp as a teaching learning tool', MVP Journal of Medical Sciences 4(1), 19-25. https://doi. org/10.18311/mvpjms/0/v0/i0/8454

Gorski, P., 2005, 'Education equity and the digital divide', AACE Journal 13(1), 3-45.

Haythornthwaite, C. \& De Laat, M., 2010, 'Social networks and learning networks: Using social network perspectives to understand social learning', paper presented at the 7th international conference on networked learning, Aalborg, 3 rd and 4th May 2010

Harrison, H., Birks, M., Franklin, R. \& Mills, J., 2017, 'Case study research: Foundations and methodological orientations', Forum: Qualitative Social Research 18(1), 1-17.

Huang, R., Michael Spector, J.H. \& Yang, J., 2019, Lecture notes in educational technology. A primer for the 21st century, Springer Nature, Singapore.

Khillar, S., 2018, Difference between WhatsApp and Facebook Messenger. Difference Between.net, viewed 28 September 2018, http://www.differencebetween.net/ technology/internet/difference-between-whatsapp-and-facebook-messenger/.

Kumar, P., 2016, Why are people choosing WhatsApp Messenger over Facebook Messenger? What can WhatsApp offer that Facebook Messenger does not? Quora, viewed 13 July 2018, from https://www.quora.com/Why-are-peoplechoosing-WhatsApp-Messenger-over-Facebook-Messenger-What-can WhatsApp-offer-that-Facebook-Messenger-does-not.

Kuklys, W., 2005, Amartya Sen's capability approach, Springer, Berling.

Lane, J.E., 2011, 'Importing private higher education: International branch campuses', Journal of Comparative Policy Analysis: Research and Practice 13(4), 367-381. Journal of Comparative Policy Analysis: Research
https://doi.org/10.1080/13876988.2011.583106

Letseka, M., Letseka, M.M. \& Pitsoe, V., 2018, 'The challenges of e-Learning in South Africa', Trends in E-learning, pp. 121-138, Intech Open. https://doi.org/10.5772/ intechopen.74843

Lincoln, Y.S., Lynham, S.A. \& Guba, E.G., 2011, 'Paradigmatic controversies, contradictions and emerging confluences, revisited', in N.K. Denzin \& Y.S. Lincoln (Eds.), The Sage handbook of qualitative research, 4th edn., pp. 97-128, Sage, Thousand Oaks, CA.

Liu, W., Sidhu, A., Beacom, A.M. \& Valente, T., 2017, 'Social network theory', in P. Rossler, C.A. Hoffner \& L. Van Zoonen (eds.), The international encyclopaedia of media effects, Wiley. https://doi.org/10.1002/9781118783764.wbieme0092

Madge, C., Breines, M.R., Dalu, M.T.B., Gunter, A., Mittelmeier, J., Prinsloo, P. et al., 2019, 'WhatsApp use among African international distance education (IDE) students: Transferring, translating and transforming educational experiences', Learning, Media and Technology 44(3), 267-282. https://doi.org/10.1080/17439 884.2019.1628048

Makoe, M., 2010, 'Exploring the use of MXit: A cell-phone social network to facilitate learning in distance education', Open Learning: The Journal of Open, Distance and e-Learning 25(3), 251-257. https://doi.org/10.1080/02680513.2010.512099

Moore, M.G., 1993, 'Theory of transactional distance', in D. Keegan (ed.), Transactional principles of distance education, Routledge, New York, NY.

Moore, J.W., 2016, 'What is the sense of agency and why does it matter?', Frontiers in Psychology 7, 1272. https://doi.org/10.3389/fpsyg.2016.01272

Mutula, S., 2008, 'Digital di-vide and economic development: Case study of subSaharan Africa', The Electronic Library 26(4), 468-489. https://doi.org/10. 1108/02640470810893738

Nabavi, R.T., 2012, Theories of developmental psychology: Bandura's social learning theory \& social cognitive learning theory, viewed 05 June 2018, from https:// www.researchgate.net/publication/267750204_Bandura's_Social_Learning_ Theory_Social_Cognitive_Learning_Theory.

Ng'ambi, D., Bozalek, V. \& Gachago, D., 2013, 'Empowering educators to teach using emerging technologies in higher education: A case of facilitating a course across institutional boundaries', in E. Ivala (ed.), Proceedings of the 8th international conference on e-Learning, pp. 292-300, The Cape Peninsula University of Technology, Cape Town, June 27-28, 2013.

Ng'ambi, D., Brown, C., Bozalek, V., Gachago, D. \& Wood, D., 2016, 'Technology enhanced teaching and learning in South African Higher Education - A review of a 20 year journey', British Journal of Educational Technology 47(5), 843-858. https://doi.org/10.1111/bjet.12485 
North, D., Johnston, K. \& Ophoff, J., 2014, 'The use of mobile phones by South African University students', Issues in Information Science and Information Technology 11 115-138. https://doi.org/10.28945/1984

Nzimande, B., 2020, Blade Nzimande's full speech on reopening the tertiary education sector, viewed 23 May 2020, from https://www.iol.co.za/news/politics/readblade-nzimandes-full-speech-on-reopening-the-tertiary-educationsector-48436840

O'Dea, S., 2020, Number of smartphone users in South Africa from 2014 to 2023 (in millions), viewed 27 Feb 2020, from https://www.statista.com/ statistics/488376/forecast-of-smartphone-users-in-south-africa/.

Pachler, N. Cook, J. \& Bachmair, B., 2010, 'Appropriation of mobile cultural resources for learning', International Journal of Mobile and Blended Learning 2(1), 1-22. https://doi.org/10.4018/jmbl.2010010101

Pimmer, C. \& Rambe, P., 2018, 'The inherent tensions of "Instant Education": A critical review of mobile instant messaging', International Review of Research in Open and Distributed Learning 19(5), 118-137.

Rambe, P. \& Bere, A., 2013, 'Using mobile instant messaging to leverage learne participation and transform pedagogy at a South African University of Technology' British Journal of Educational Technology 44(4), 544-561.

Rambe, P. \& Ng'ambi, D., 2014, 'Learning with and from Facebook-uncovering power asymmetries in educational interactions', Australasian Journal of Educational Technology 30(3), 312-325. https://doi.org/10.14742/ajet.116

Resta, P. \& Laferrière, T., 2007, 'Technology in support of collaborative learning', Educational Psychology Review 19(1), 65-83. https://doi.org/10.1007/s10648007-9042-7

Robeyns, I., 2011, The capability approach. Stanford encyclopedia of philosophy, viewed 10 August 2018, from http://plato-stanford.edu/archives/sum2011/entries/ capability-approach

Rosenberg, J.P. \& Yates, P.M., 2007, 'Schematic representation of case study research designs', Journal of Advanced Nursing 60(4), 447-452.

Sayan, H., 2016, 'Affecting higher students learning activity by using WhatsApp', European Journal of Research and Reflection in Educational Sciences 4(3), 88-93.

Scardamalia, M. \& Bereiter, C., 2006, 'Knowledge building: Theory, pedagogy and technology', in R.K. Sawyer (ed.), Cambridge handbook of the learning sciences, pp. 97-118, Cambridge University Press, New York, NY.

Schrage, M., 1990, Shared minds: The new technologies of collaboration, Random House, New York, NY.

Sen, A., 1985a, 'Wellbeing, agency and Freedom: The John Jewey Lectures 1984', The Journal of Philosophy 82(4), 169-221. https://doi.org/10.2307/2026184

Sen, A., 1985b, Commodities and capabilities, North-Holland, Amsterdam.

Sen, A., 1987a, The standard of living, Cambridge University Press, Cambridge.

Sen, A., 1987b, 'Freedom of choice: Concept and content', in Alfred Marshal Lecture at the annual meeting of the European Economic Association, Copenhagen, 22 August, 1987.
Sen, A., 1992, Inequality Re-examined, Russell Sage and Harvard University Press, New York, NY.

Sen, A.K., 1999, Development as freedom, Anchor Books, New York, NY.

Sen, A., 2000, Social exclusion: Concept, application, and scrutiny, Social Development Papers No. 1, Office of Environment and Social Development, Asian Development Bank, Manila, Phillipines.

Shava, H., Chinyamurindi, W. \& Somdyala, A., 2016, 'An investigation into the usage of mobile phones among technical and vocational educational and training students in South Africa', South African Journal of Information Management 18(1), a716. in South Africa', South African Journal of
https://doi.org/10.4102/sajim.v18i1.716

Stake, R., 2006, Multiple case study analysis, Guilford, New York, NY.

Tondeur, J., Sinnaeve, I., Van Houtte, M. \& Van Braak, J., 2010, 'ICT as cultural capital: The relationship between socioeconomic status and the computer-use profile of young people', New Media \& Society 13(1), 1-18. https://doi.org/10.1177/ 1461444810369245

Traxler, J., 2007, 'Defining, discussing, and evaluating mobile learning: The moving finger writes and having writ...', International Review of Research in Open and Distance Learning 8(2), 1-12. https://doi.org/10.19173/irrodl.v8i2.346

Verma, U., 2019, WhatsApp vs. Facebook Messenger: 5 main differences users should know, viewed 07 January 2019, from https://www.businesstoday.in/buzztop/ buzztop-feature/whatsapp-vs-facebook-messenger-5-main-differences-usersshould-know/story/306784.html.

Voogt, J., Knezek, G., Cox, M., Knezek, D. \& Brummelhuis, A., 2011, 'Under which conditions does ICT have a positive effect on teaching and learning? A call to action', Journal of Computer Assisted Learning 29(1), 4-14.

Vygotsky, L.S., 1978, Mind in society, Harvard University Press, Cambridge, MA.

Waters, J. \& Leung, M., 2013, 'Immobile transnationalisms? Young people and their in-situ experiences of international education in Hong Kong', Urban Studies 50(3), 606-620. https://doi.org/10.1177/0042098012468902

Weinberg, G., 2020, What are some simple steps I can take to protect my privacy online? viewed 07 August 2018, from https://www.quora.com/What-are-somesimple-steps-I-can-take-to-protect-my-privacy-online

WhatsApp, 2020, viewed 05 January 2020, from http://www.whatsapp.com/ download/.

Willemse, J.J., 2015, 'Undergraduate nurses' reflections on Whatsapp use in improving primary health care education', Curationis 38(2), Art. \#1512. https://doi.org/ 10.4102/curationis.v38i2.1512

Woods, N.F. \& Calanzaro, M., 1980, Nursing research: Theory and practice, Mosby, St Louis, MO.

Webb, M., 2011, 'Changing models for researching pedagogy with information and communications technologies', Journal of Computer Assisted Learning 29(1), communications technologies', Journal of Computer Assist
53-67. https://doi.org/10.1111/j.1365-2729.2011.00465.x

Yin, R.K., 2003, Case study research: Design and methods, 2nd edn., Sage, Thousand Oaks, CA

Yin, R.K., 2014, Case study research: Design and methods, Sage, Los Angeles, CA 